\title{
Effect of smoking processes on the contents of 10 major phenolic compounds in smoked fillets of herring (Cuplea harengus)
}

\author{
Thierry Sérot*, Régis Baron, Camille Knockaert and Jean Luc Vallet
}

Laboratoire de Génie Alimentaire. IFREMER Centre de Nantes, 3 Rue de l'lle d'Yeu, BP 21105, 44311 Nantes,

Cedex 3, France

*tserot@ifremer.fr Tel.: +33-02-4037-4252; fax: +33-02-4037-4001

\begin{abstract}
This study evaluated the effects of five smoking processes on the contents of 10 major phenolic compounds in fillets of herring (Cuplea harengus), namely two traditional processes, involving smoke production by smouldering or friction, one process using liquid smoke atomisation, and two electrostatic smoking processes, also involving smouldering or friction. The effects of several parameters, such as smoking time, smokehouse temperature, electrode voltage, and fish fillet temperature before smoking were assessed for each process. The results indicate that the content of phenolic compounds are strongly affected by the process applied. The percentages of phenolic compounds in fish flesh remained constant and discriminant for a given process, regardless of the parameters studied, which implies that the smoking process used can be identified by determination of phenolic compounds in fish.
\end{abstract}

Keywords: Smoking process; Phenolic compounds; Herring 


\section{Introduction}

In the traditional technique of smoking to preserve fish, phenolic compounds are of considerable importance for the preservation and organoleptic properties of smoked products (Kjallstrand \& Petersson, 2001). The relative concentration of phenolic compounds in these products depends on the nature of the wood used in the smoking process (Guillen \& Marzanos, 1999; Guillen \& Iibargotra 1996). The method of smoke generation and the smoking process used (Cardinal, M., Berdagué, J.L., Dinel, V., Knockaert, C., \& Vallet J.L. 1997) have a considerable influence on the sensory characteristics of smoked salmon. The chemical features of meat smoking have been investigated (Girard, Talon, \& Sirami, 1982; Borys, 1995), and the composition of dry or liquid smoke has been assessed in several studies (Guillen \&. Manzanos, 1996; Guillen \& Ibargoitia, 1998; Kjällstrand, \& Petersson, 2001). However, few data are available on the composition of phenolic compounds in smoked fish. In fact, different methods and types of equipment are used for smoke production and deposition, but their impact on the content of phenolic compounds in fish muscle has not been extensively evaluated. According to Girard \& Talon (1982), electrostatic smoking, as compared to the traditional smokehouse process, increased the content of phenolic compounds in bacon. A study by Chan \& Toledo (1975) concerning smokehouse production of smoked mackerel, using smoke production from moist hickory sawdust, showed that concentrations of phenolic compounds in fish muscle increased up to $75^{\circ} \mathrm{C}$ and then decreased. According to these authors, maximum smoke deposition was achieved at $60 \%$ relative humidity.

A good understanding of the fish smoking process is required to define the best conditions for obtaining good product quality. The present study investigated the effects of five smoking processes on the content of ten phenolic compounds in herring fillets. The ten compounds (phenol, p-cresol, o-cresol, guaiacol, 4-methyl guaiacol, 4-ethyl guaiacol, syringol, eugenol, 
4-propyl guaiacol, and isoeugenol) had previously been identified as major components of smoked fish (Sérot \& Lafficher 2003). The processes studied were the traditional smokehouse method in which smoke is produced by pyrolysis of sawdust or by friction, atomisation of liquid smoke in a smokehouse, and continuous electrostatic smoking (Collignan, Knockaert, Raoult-Wack and Vallet,1992) in which smoke is also produced by pyrolysis of sawdust or by friction. The effects on the deposition of phenolic compounds were evaluated for smoking time, smokehouse temperature, smoke residence time in the smokehouse, initial temperature of fish fillets, and the difference in electrode potential (for the electrostatic smoking process). The same hardwood (beech) was used for all comparisons. 


\section{Materials and methods}

\section{Reagents}

Phenol compounds (phenol, p-cresol, o-cresol, guaiacol, 4-methyl guaiacol, 4-ethyl guaiacol, syringol, eugenol, 4-propyl guaiacol, isoeugenol and 2-chlorophenol; purity >99\%) were purchased from Sigma-Aldrich (l’Ile d'Abeau, France). Stock standard solutions of phenolic compounds were prepared by dissolution in HPLC grade methanol from Carlo Erba (Val de Reuil, France). All solutions were stored in brown glass bottles at $-20^{\circ} \mathrm{C}$.

\section{Processing equipment.}

All processes and parameters used for this study are summarised in table 1.

The smokehouse was an HMI Thirode (PC90 Model) device (Thirode, France), 1.500 x 1.300 x $2.250 \mathrm{~mm}$ with a capacity of $380 \mathrm{~kg}$, mounted on a trolley with 28 grids. The air/smoke circulation was horizontal. The electrostatic smoking method (Collignan, A., Knockaert, C., Raoult-Wack, A.L., \& Vallet, J.L. (1992); Bardin, Desportes, Knockaert \& Vallet, 1997) was performed using an experimental tunnel $4.000 \times 100 \times 150 \mathrm{~mm}$. This facility allowed continuous smoking of $125 \mathrm{Kg} / \mathrm{h}$. The tension applied between the discharge electrode (corona effect)) and the collecting electrode (conveyor belt) was set by an HT14B high voltage supply (Sefelec, France). Air speed above the fillet was around $0.5 \mathrm{~m} . \mathrm{s}^{-1}$.

A generator (Thirode, France) produced smoke by pyrolysis $\left(450^{\circ} \mathrm{C}\right)$ of beech wood sawdust using the smouldering method, and another generator (Muvero, the Netherlands) produced smoke by friction at $350^{\circ} \mathrm{C}$, using a beech wood beam at $350^{\circ} \mathrm{C}$.

Liquid smoke, used for atomisation (vaporisation) in the smokehouse, as previously described, was referenced by the code 1165 (Lutetia, France). It is a purified condensate of beech smoke associated with aromatic additives. Tests beforehand determined that this smoke was similar to that produced in "traditional fish smoking” with beech wood in a smokehouse. 
Beech wood was used for all processes to minimise the influence of this parameter in the study.

\section{Fish samples}

Frozen herring fillets were obtained from a local fish and seafood wholesaler (Nantes, France). After thawing in a refrigerated room at $+4^{\circ} \mathrm{C}$ for $6 \mathrm{~h}$, fillets were hand-salted with refined salt (Salins du Midi, France), left sit for $20 \mathrm{~min}$ at $12^{\circ} \mathrm{C}$, and then rapidly rinsed with water $\left(15^{\circ} \mathrm{C}\right)$ before being stored in a cold room at $+2^{\circ} \mathrm{C}$ for approximately $14 \mathrm{~h}$ until smoking.

Just before extraction, fish fillets (50 g) were minced in a Waring blender and then homogenised (Ultraturax T25 IKA, 7,500 rpm) in $100 \mathrm{ml}$ of a $30 \% \mathrm{NaCl}$ solution acidified to pH 2.

Simultaneous steam distillation solvent extraction (SDE). Simultaneous steam distillation of smoke compounds was performed in a Likens-Nickerson (1964) apparatus, as described by Tanchotikul \& Hsieh (1989).

A $500 \mathrm{~mL}$ round-bottom flask was used for fish preparation. Fifty milliliters of $\mathrm{NaCl}$ solution were used to rinse the vessel and then added in the flask. Five hundred microliters of a 2 chlorophenol solution $(0.1 \mathrm{mg} / \mathrm{ml})$ were added as internal standard (IS). A $100 \mathrm{~mL}$ conical-bottom flask containing $35 \mathrm{~mL}$ of distilled dichloromethane was attached to the solvent arm of the SDE apparatus. Contents of the sample and solvent flasks were heated to the boiling point, and distillation/extraction was then continued for $3 \mathrm{~h}$. The volume of SDE extracts was dried over $2 \mathrm{~g}$ of anhydrous sodium sulphate and then reduced to $2 \mathrm{~mL}$ in a Kuderna Danish Concentrator and finally to exactly $1 \mathrm{ml}$ under a gentle stream of nitrogen. The SDE extracts were stored at $-20^{\circ} \mathrm{C}$ in glass vials with Teflon-lined caps. Prior to gas chromatography analysis, phenolic compounds were silylated. Fifty microliters of 
BSTFA+TMS reagent were added to $250 \mu$ of extract placed in a vial. Derivatization was then performed at room temperature for $2 \mathrm{~h}$.

\section{Gas chromatography}

Gas chromatography analysis was performed on a Trace GC 2000 apparatus (ThermoFinnigan, Les Ulis, France) equipped with a split/splitless injector and FID detector. A capillary column (DB1, J\&W Scientific, Folsom, CA, USA; 30m x 0.25 mm I.D. $d_{\mathrm{f}}=0.25$ $\mu \mathrm{m})$ was used to separate phenolic compounds. Sample volumes of $1 \mu \mathrm{L}$ were injected. Injector and detector temperatures were $280^{\circ} \mathrm{C}$, the flow rate of carrier gas (helium) was 1.5 $\mathrm{mL} / \mathrm{min}$, and oven temperature was programmed from $50^{\circ} \mathrm{C}(1 \mathrm{~min})$ to $80^{\circ} \mathrm{C}(1 \mathrm{~min})$ at $4^{\circ} \mathrm{C} / \mathrm{min}$, then to $150^{\circ} \mathrm{C}$ at $2^{\circ} \mathrm{C} / \mathrm{min}$, and finally to $280^{\circ} \mathrm{C}(10 \mathrm{~min})$ at $10^{\circ} \mathrm{C} / \mathrm{min}$. Chromatographic data acquisition and processing were carried out using ChromCard software version 1.07 (Thermoquest, Milan, Italy). The content of phenolic compounds, expressed in mg/100 g of fish muscle, was obtained by calculations from calibration curves.

\section{Statistical analysis}

All statistical tests were performed using Statgraphics plus software, version 4.0 (Manugistics, Rockville, MD, USA).

\section{Results and discussion}

Figure 1 shows the effects of the smoking process on the content of the ten studied phenolic compounds in smoked herring fillets. Smoking at $24^{\circ} \mathrm{C}$ and $32^{\circ} \mathrm{C}$ with liquid smoke vaporization (ls) allowed the deposition of a high quantity of phenolic compounds (Figure 1A). However, when smokehouse temperature was set at $16^{\circ} \mathrm{C}$, few compounds were deposited, probably because of low vaporisation of the liquid smoke at this temperature. For the traditional smoking process, smoke production by pyrolysis of sawdust (sp) (Figure 1D) allowed deposition of more important quantities of phenolic compounds than smoke 
production by friction (fp) (Figure 1B). The content of phenolic compounds in fillets smoked by the electrostatic smoking process was low (Figure 1C). However, it can be note that smoke production by pyrolysis of sawdust (es) was more efficient than by friction (ef). Talon et al. (1982) have shown that the rate of phenolic compounds adsorption for bacon was higher with electrostatic than traditional smoking. However, the smoking process was not continuous in their study, and processing time was set at 1 and $2 \mathrm{~h}$. In the case of traditional processes in our study, initial absorption of phenolic compounds was relatively rapid, followed by a reduction of absorption until a saturation level was reached (Figure 2). The shape of the phenolic compounds deposition curve could have been due to drying out of the fish fillet surface during smoking and to more gradual smoke deposition on dry surfaces (Chan \& Toledo, 1975). For the liquid smoke process, the kinetic curve of phenolic compounds deposition resembles an exponential curve, with a rapid increase of deposition after $180 \mathrm{~min}$. This curve shape could have been due to a progressive increase of smoke vapour in the smokehouse.

Figure 3 shows that guaiacol and 4-methylguaiacol were the main compounds in fish fillets smoked according to traditional and liquid smoke atomisation processes. When electrostatic smoking process was used, with smoke production by friction, syringol was the second leading compound after guaiacol The content of syringol and 4-methylguaiacol was not significantly different for electrostatic smoking with smoke production by sawdust pyrolysis. Figure 3A,B,C shows that the third leading compound was syringol for the traditional process and phenol for liquid smoke atomisation. This difference could have been due to the low vapour tension of syringol, which is deposited in smaller amounts than phenol when liquid smoke is used. Regardless of the process used, the least deposited compounds (in descending order) were eugenol, 4-ethylguaiacol, o-cresol, p-cresol, and 4-propylguaiacol. This order could relate to the chemical structure of these compounds and the possibility of establishing 
bonds with fish flesh components. However, this hypothesis requires further investigation. The various parameters of the smoking process studied had no effect on this order.

A one-way analysis of variance (ANOVA) showed that the mean of content from one level of process for all studied phenolic compounds was significantly different to another at the 95\% level of confidence (P-value $<0.05$ ). A Fischer's least significant difference (LSD) test was used to determine which mean contents were significantly different from which others. The results of the LSD procedure indicated that the phenol content of fillets smoked by "sp" and "Ip” processes was significantly different from that of fillets smoked by the other processes (Figure 4A). The phenol content of fillet smoked by the "fp” process was significantly different from that of fillets smoked by the "ef" process, but not from that of fillets smoked by the "es” process. No significant differences were observed between the phenol content of fillets smoked by both electrostatic processes. Analysis of guaiacol content identified two homogeneous groups (Figure 4B), one consisting of samples smoked by "sp”, "ls”, and "fp” processes and showing a high level of guaiacol, and the other consisting of samples smoked by both electrostatic processes and showing lower guaiacol content. Analysis of syringol content distinguished four homogeneous groups (Figure 4C) consisting, respectively, of fillets smoked by the "sp” process, "Is" and “es” processes, “es” and “fp” processes, and "fp” and “ef” processes. The LSD procedure performed on the content of 4-methylguaiacol, o-cresol, p-cresol, and 4-ethylguaiacol distinguished three groups consisting of samples smoked by "sp" and "ls” processes, the "fp" process, and the two electrostatic processes. This analysis indicated the great variability in phenolic compounds content for the different smoking processes, independently of the parameters studied. These results are consistent with those of Grondin \& Guillard (2000), who showed that the content of phenolic compounds is characteristic of a given smoking process. 
To determine which phenolic compounds contribute most to the characterisation of the smoking processes, factorial discriminant analysis (FDA) was performed for the percentages of the ten phenolic compounds in fillets smoked by the five processes. The use of percentages allowed us to disregard the effect of smoking parameters, particularly smoking time. In any case, the percentages for phenolic compounds were constant for a given smoking process independently of the parameters (Table 2) while their content increased with smoking time or temperature. Figure 5 shows the factorial plane of the two first canonical factors of the discriminant analysis. Five groups corresponding to the five processes were discriminated. Discrimination of the smoking processes was very good, because $98.8 \%$ of the observations were correctly assigned to their original group after re-substitution. Only one observation from the "ls" group was assigned to the "sp" group. The equation for the first standardised discriminating function,

0.615 phenol +0.853 o-cresol -0.868 p-cresol -1.082 guaiacol +0.801 4-methylguaiacol 0.103 4-ethylguaiacol -0.729 syringol -0.950 eugenol +0.114 4- propylguaiacol -0.184 isoeugenol, shows that guaiacol, eugenol, p-cresol, o-cresol and 4-methylguaiacol (in decreasing order) strongly contribute to the discrimination of the five groups. These results confirm that the composition of the phenolic compounds differs according to the smoking process used (Borys, 1996; Grondin \& Guillard, 2001) and suggest that this factor could be useful for analysis and identification of the particular smoking process applied to fish fillets.

Multifactoral ANOVA was performed relative to the content of the ten phenolic compounds in herring fillets subjected to smouldering, friction and liquid smoke processes. The results indicate that smoking time, smokehouse temperature, the process involved, and interaction among these factors had significant effects on the deposition of phenolic compounds in fish fillets (P value $<0.05$ ). In particular, the increased deposition of all phenolic compounds with 
time was greater when temperature increased (Figure 6A for guaiacol content). This could have been due to an increase of phenolic compounds in the vapour phase at high temperature or to modifications of the physical state of matrix components, particularly higher fluidity of the lipid phase, which could have contributed to the solubilisation of the phenolic compounds. Analysis of smoking time and process interactions (Figure 6B) confirms the previous observations, this phenomenon could have been due to the drying out of the fillet surface. When smoke production involving smouldering and friction, a saturation level for deposition was reached after $3 \mathrm{~h}$, whereas an exponential increase of deposition was observed for liquid smoke. Vaporisation of liquid smoke probably prevents drying out of the fillet surface. A study of the interaction between temperature and the process indicated that the deposition rate was very rapid for liquid smoke vaporisation, with an approximately linear increase between 16 and $32^{\circ} \mathrm{C}$, whereas the increase of deposition was very gradual for the smouldering smoke production between 16 and $24^{\circ} \mathrm{C}$ and then more rapid from 24 to $32^{\circ} \mathrm{C}$ (Figure 6C). The same type of curve was apparent (though less marked) when friction smoke production was used. The effect of the opening of the exhaust valve of smokehouse was only tested for smouldering and friction processes, as the exhaust valve remained closed for liquid smoke. ANOVA results indicated that the effect of exhaust valve position was highly significant. Analyses of the interaction between smoking time and exhaust valve position and between smoking temperature and exhaust valve position showed that the content of phenolic compounds in fillets was significantly higher when the exhaust valve was one-third open, smokehouse temperature was low $\left(16^{\circ} \mathrm{C}\right)$, and smoking time was at least $240 \mathrm{~min}$. This observation, which was valid for all studied compounds, implies that for low temperature, the level of deposited compounds is greater to the extent that residence time is longer. Chan \& Toledo (1975) have shown that the rate of smoke deposition was faster and a higher concentration was obtained when air is circulated through the smokehouse (10 volume changes/min). 
Multifactoral ANOVA was performed to evaluate the effect of smoking time, tension, and smoke production on the deposition of phenolic compounds when the electrostatic process was used. With respect to the content of the ten phenolic compounds, Fischer's LSD procedure identified two homogeneous groups corresponding to two smoke production processes. The interaction between smoking time and the process (Figure 8A) shows that the content of phenolic compounds in herring fillets obtained with smouldering smoke production was significantly higher than that obtained with friction smoke production. The kinetics for the deposition of phenolic compounds was approximately linear. This is quite surprising, as some studies have shown that friction smoke contains more phenolic compounds than sawdust smoke (Husaini \& Cooper, 1957). However, the greater moisture of sawdust smoke could have increase the individual particulate charge (correlated with greater conductivity). On the other hand, the smoke generation temperature affects the phenolic compounds of smoke (Toth 1980). If the temperature of sawdust pyrolysis is set at $450^{\circ} \mathrm{C}$ and that of beam pyrolysis at $350^{\circ} \mathrm{C}$, the content of phenolic compounds would be higher for the former than the latter. Analysis of the interactions between voltage and the process (Figure 8A) shows that the deposited amounts of the ten phenolic compounds were significantly higher with smouldering when voltage was set at $37 \mathrm{kV}$ than at $42 \mathrm{kV}$, whereas no difference between the two voltages was apparent with friction. It is not easy to explain these results, and further investigations are needed to determine smoke composition before and after electrostatic precipitation at different voltages and to analyse the reproducibility of electrostatic precipitation of smoke compounds.

The effect of the initial temperature of fish fillets on the deposition of phenolic compounds was only tested for the electrostatic process with smoke production by friction. The results of multifactoral ANOVA show that smoking time, initial fillet temperature, and the interaction between time and temperature had a significant effect on the content of all phenolic 
compounds. When fish fillet temperature was set at $20^{\circ} \mathrm{C}$, content was higher than when the temperature was set at $10^{\circ} \mathrm{C}$, regardless of smoking time (Figure 9A,B). The lower level of deposited phenolic compounds obtained at $10^{\circ} \mathrm{C}$ may have been due to condensation of water vapour on the surface of cold fillets, resulting in the washing out of deposited smoke compounds (Chan \& Toledo, 1975). A higher temperature would have prevented this condensation. 


\section{Conclusion}

Deposition kinetics and the amount of phenolic compounds deposited are in close relation to the smoking process used. Liquid vaporisation allows the deposition of a large amount of compounds at $32^{\circ} \mathrm{C}$. Guaiacol and 4-methylguaiacol exhibit some of the highest contents in smoked flesh fish, regardless of the process used. The content of the ten studied phenolic compounds differed significantly according to the process used and the parameters of the smoking process. The effects of interactions between these parameters are highly significant, however the impact of the parameters differs from one process to another. In particular, the effect of interaction between smoking time and temperature is very important when traditional and liquid smoke vaporisation processes are used. The electrostatic process, in our conditions, did not allow high deposit levels for phenolic compounds. As in the traditional process, the method of smoke production seemed to a have a decisive effect on the deposition of phenolic compounds. Other parameters, particularly voltage setting, require further investigation This study also showed that phenolic compounds composition of smoked fish fillets depends on the smoking process used but is independent of the parameters studied. Discriminant analysis applied to percentages of the ten phenolic compounds found in fillets would appear to be a particularly suitable method for identifying the smoking process used to smoke fish fillets.

Specific study will be necessary to evaluate the effects of the content of phenolic compounds on organoleptic properties and shelf life of smoked herring fillets. 
Borys, A. (1995). Content of smoke components in some meat products. Roczniki-InstytutuPrzemyslu-Miesnego-i-Tluszczowego, 32/33, 203-212.

Bardin, J.C., Desportes G., Knockaert, C., \& Vallet, J.L. (1997) Améliorations du procédé de fumage électrostatique de produits carnés - French patent 9708177.

Cardinal, M., Berdagué, J.L., Dinel, V., Knockaert, C., \& Vallet J.L. (1997). Effet de differentes techniques de fumage sur la nature des composes volatiles et les caractéristiques sensorielles de la chair de saumon. Sciences des Aliments, 17, 680-696.

Collignan, A., Knockaert, C., Raoult-Wack, A.L., \& Vallet, J.L. (1992) Procédé et dispositif de salage-séchage et de fumage à froid de produits alimentaires carnés. French patent 9208958, European extension 93430009.6.

Girard, J.P., Talon, R., \& Sirami, J. (1982). Le fumage électrostatique: son efficacité relativement à deux parameters. Sciences des Aliments, 2, 1-15.

Guillen, M.D., \& Ibargoitia, M.L. New components with potential antioxidant and organoleptic properties, detected for the first time in liquid smoke-flavoring preparations. Journal of Agricultural and Food Chemistry, 46 (1998) 1276-1285.

Guillen, M.D., \&. Manzanos, M.J. (1996) Study of the components of a solid smoke flavouring preparation. Food-Chemistry, 55 (3), 251-257.

Husaini, S.A. and Cooper, G.E. (1957). Fractionation of wood smoke and the comparison of chemical composition of sawdust and friction smokes. Food technology, 11, 499-502.

Kjällstrand, J., \& Petersson, G. (2001). Phenolic antioxidants in wood smoke. The Science of the Total Environment, 27, 69-75.

Chan, W.S., Toledo, R. (1975). Effect of smokehouse temperature, humidity and air flow on smoke penetration into fish muscle. Journal of Food Science, 40, 240-243.

Likens, S.T.; Nickerson, G.B. (1964). Detection of certain hop oil constituents in brewing products. Am. Soc. Brew. Chem. Proc., 5-13.

Tanchotikul, U.; Hsieh, T. C.Y. (1989). Volatile flavor components in crayfish waste. J. Food Sci., 54, No. 6, 1515-1520.

Toth, L. (1980). Separation and analysis of phenol fractions from smokehouse smoke. II. Separation, purification and analysis of phenol fractions. Fleischwirftschaft, 60, 728-732. 


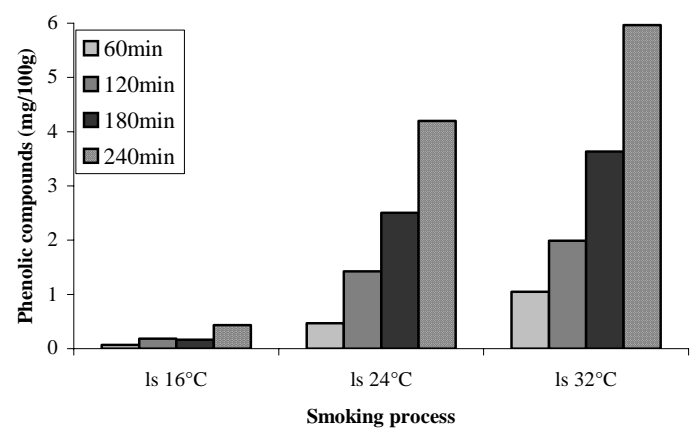

A: liquid smoke vaporisation (ls)

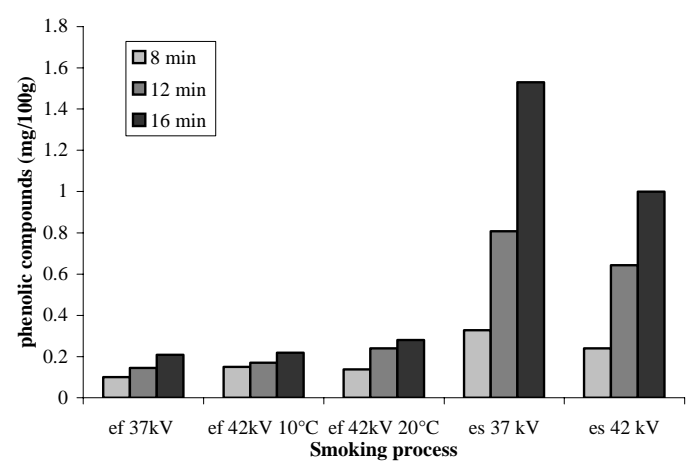

C: electrostatic smoking (es: smouldering, ef: friction)

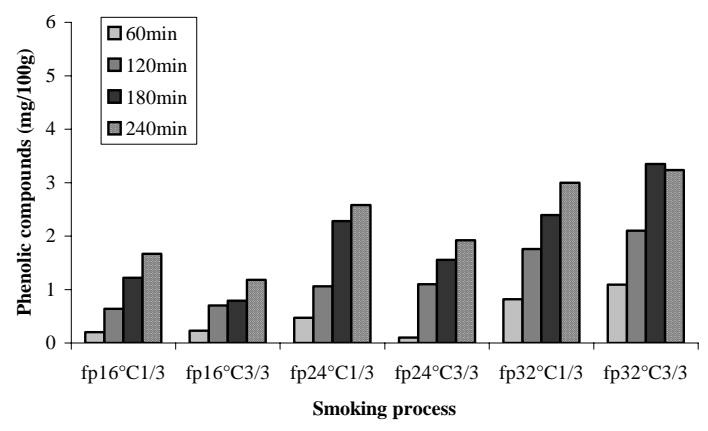

B: friction smoke production (fp)

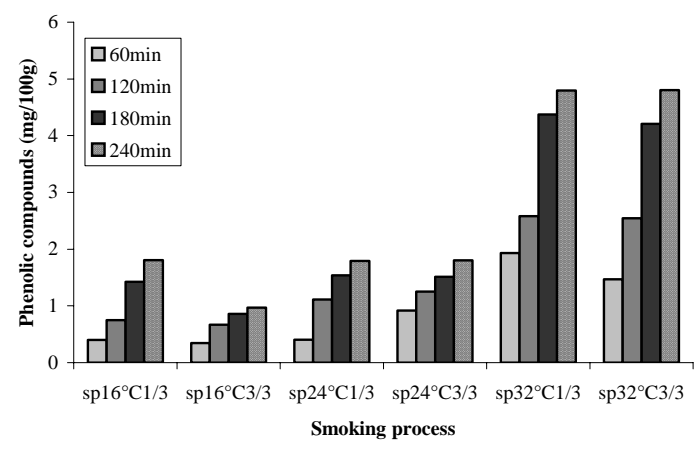

D: smouldering smoke production (sp)

Fig.1. Comparison of the effect of process and parameters of process on the sum of the ten phenolic compounds in smoked herring fillets. (smokehouse temperature was set at 16, 24, or $32^{\circ} \mathrm{C} ; 10$ and $20^{\circ} \mathrm{C}$ indicate the initial temperature of fillets; 37 and $42 \mathrm{KV}$ indicate the voltage for electrostatic process; $1 / 3$ and $3 / 3$ indicate the opening position of exhaust valve) 


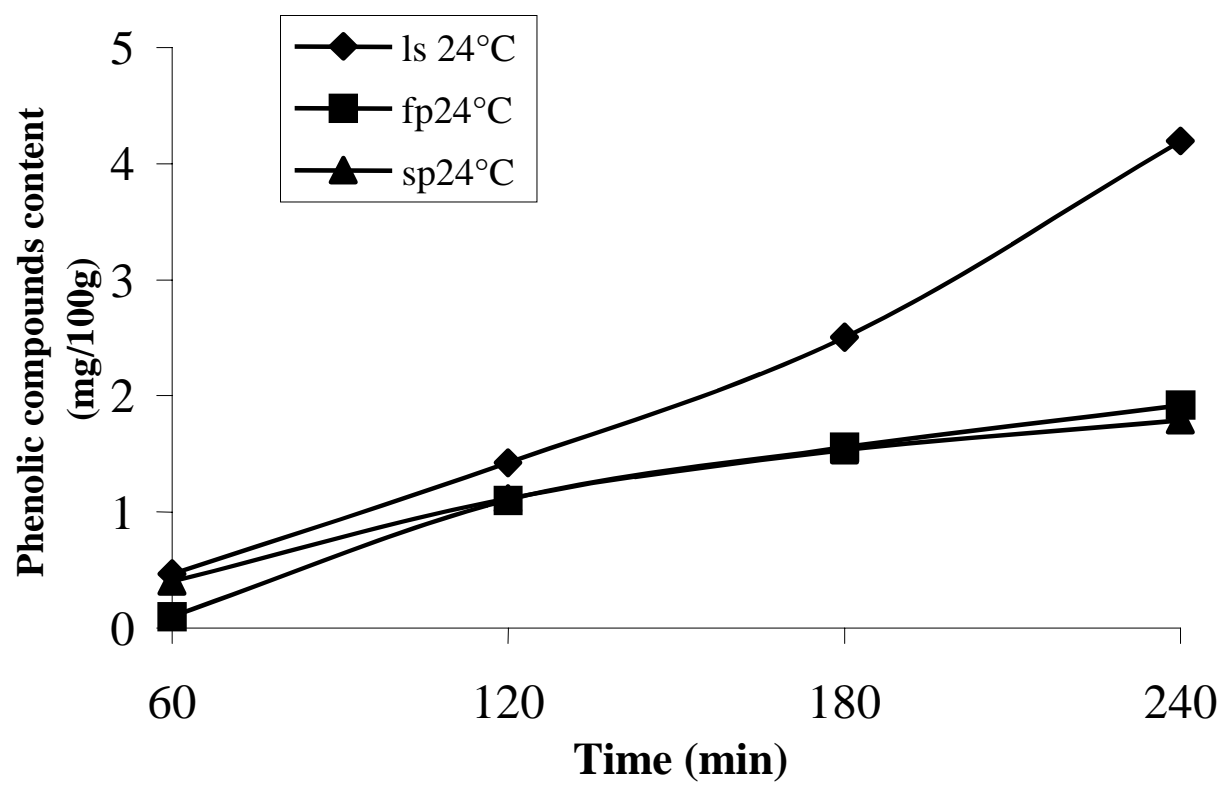

Fig. 2. Effect of smoke generation on the sum of the ten major phenolic compounds content of smoked herring fillets. 


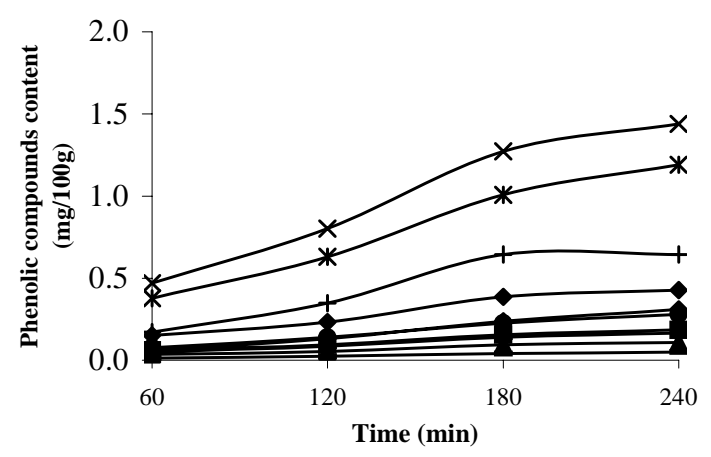

A

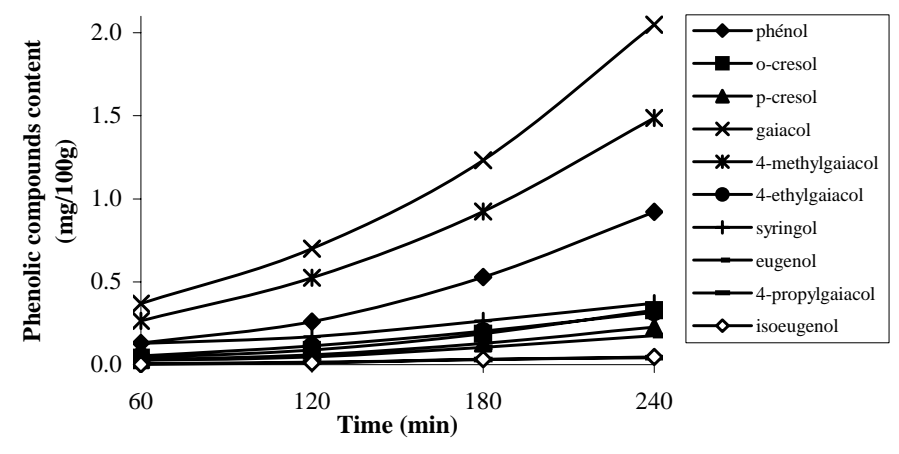

C

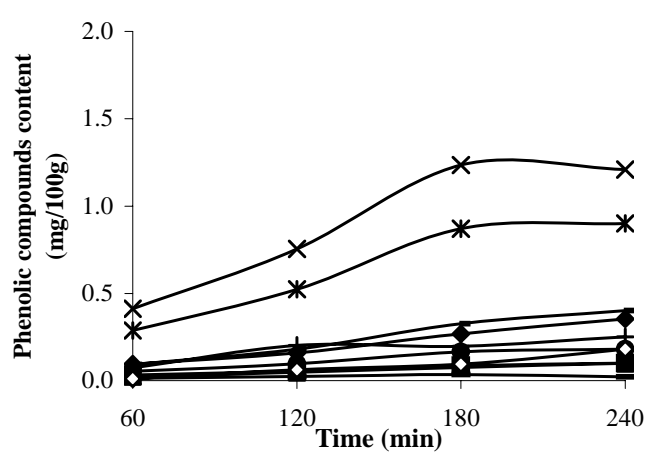

B

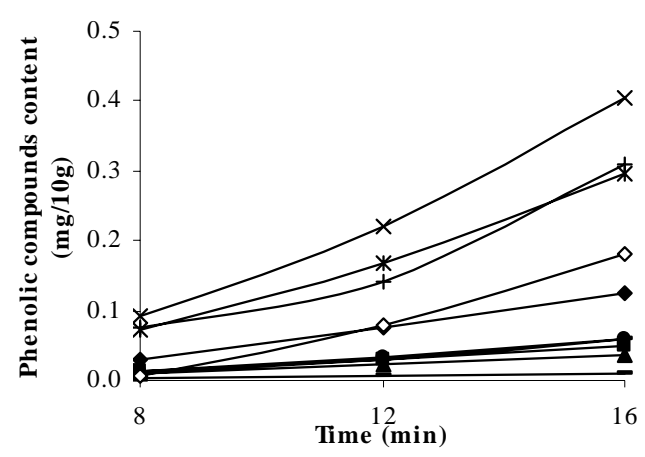

$\mathrm{D}$

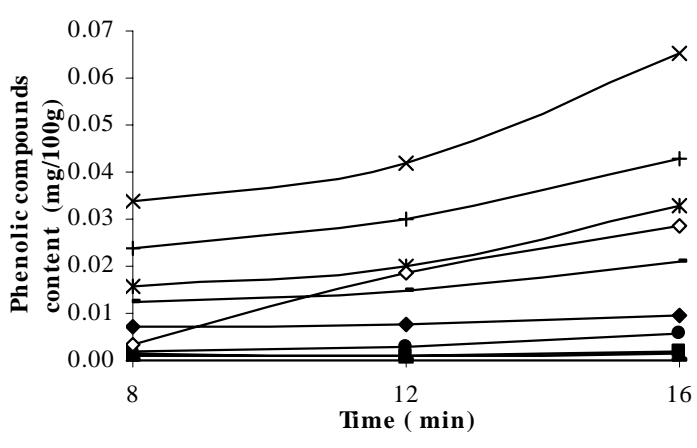

$\mathrm{E}$

Fig.3. Comparison of the effect of smoking time on content of phenolic compounds in herring fillets obtained by the five studied smoking processes (A: sp $\left(\theta^{\circ}: 32^{\circ} \mathrm{C}\right.$, exhaust valve: $3 / 3) \mathrm{B}$ : fp $\left(\theta^{\circ}: 32^{\circ} \mathrm{C}\right.$, exhaust valve: $\left.3 / 3\right) \mathrm{C}$ : Is $\left(\theta^{\circ}: 32^{\circ} \mathrm{C}\right)$ D: es $\left(\theta^{\circ}\right.$ fillet: $10^{\circ} \mathrm{C}$, $\mathrm{U}=37 \mathrm{KV}) \mathrm{E}$ : ef $\left(\theta^{\circ}\right.$ fillet: $\left.20^{\circ} \mathrm{C}, \mathrm{U}=37 \mathrm{KV}\right)$. 


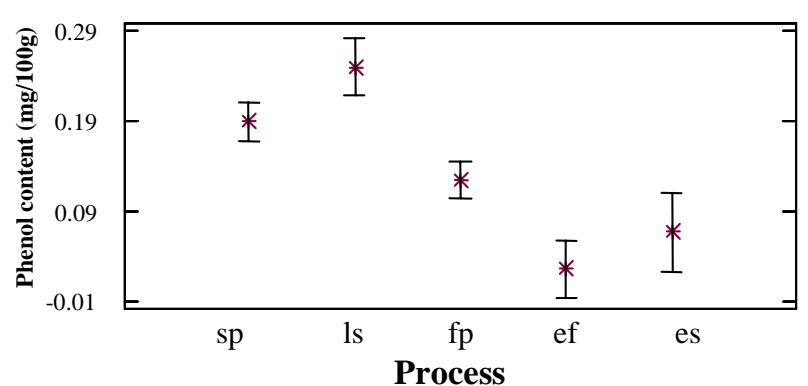

A

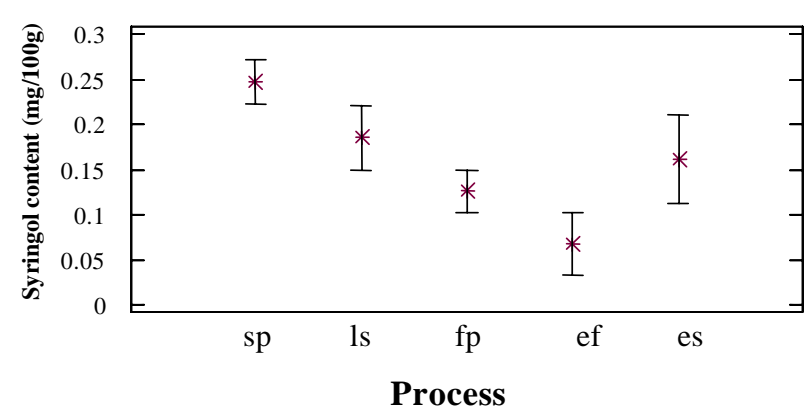

C

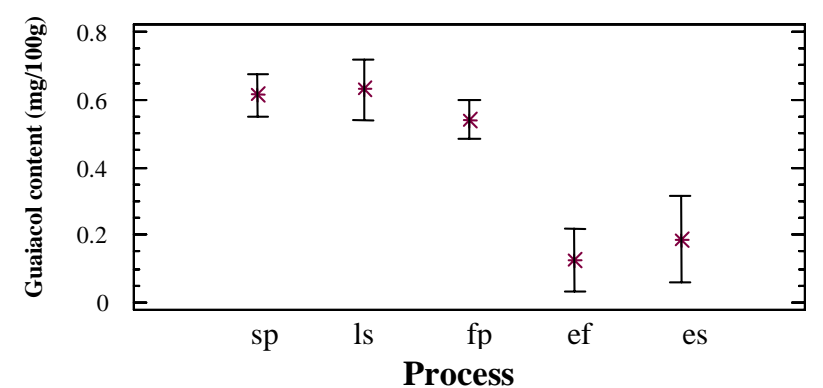

B

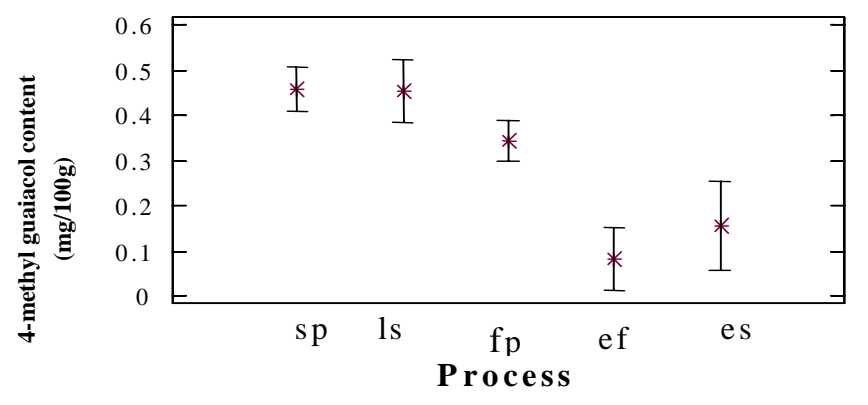

D

Fig.4. Comparison of phenolic compounds content means obtained by using the five smoking processes, for all tested parameters. 95.0 percent LSD intervals are plotted. 


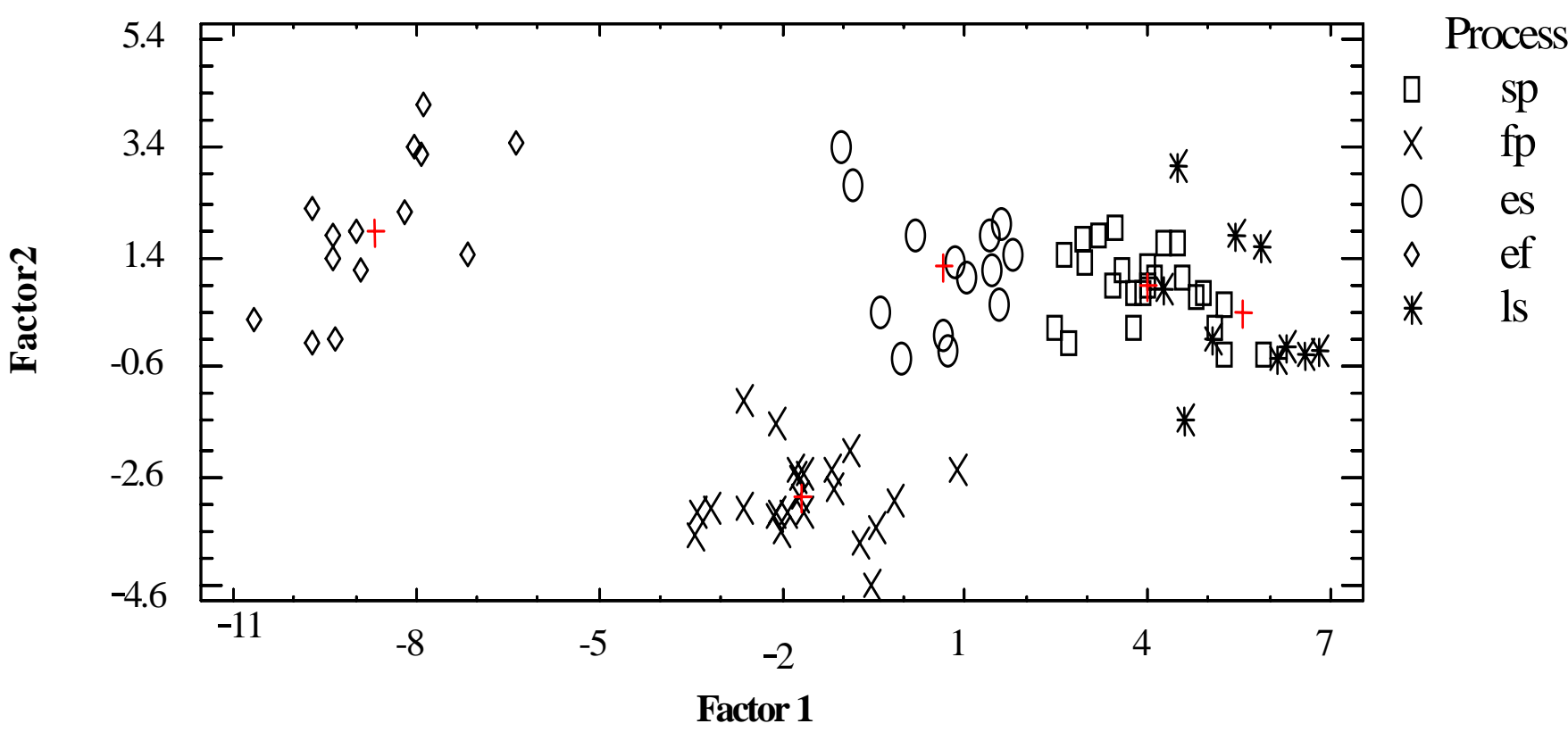

Fig. 5. Projection o the 84 samples on the plane of both first canonical factors of the discriminant analysis. 


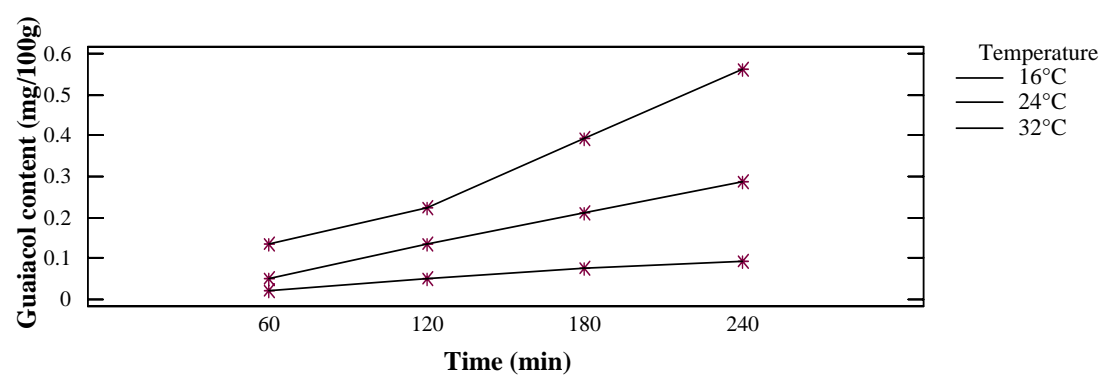

A

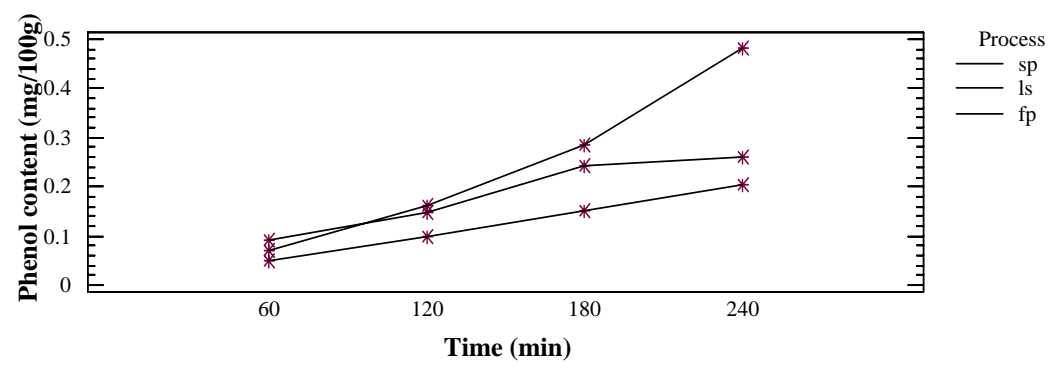

$\mathrm{B}$

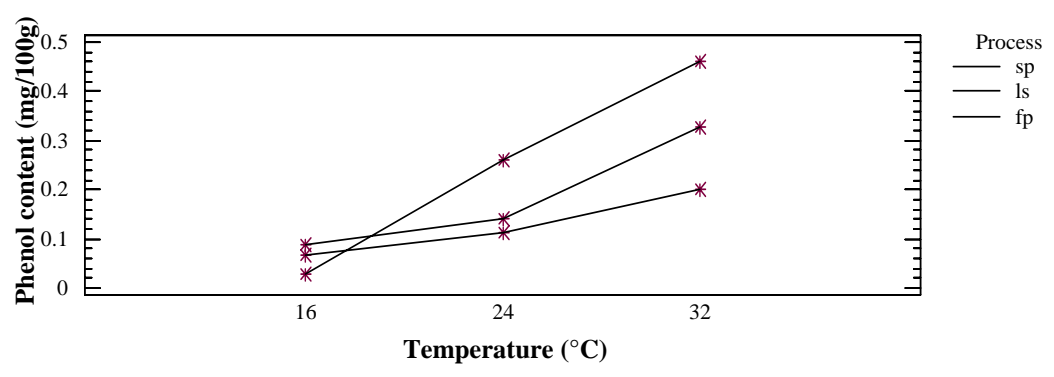

C

Fig. 6. Effect of smoking time and temperature and smoke production method on content of phenolic compounds in smoked herring filets. (A: plot of interaction temperature-time, B: plot of interaction process-time, C: plot of interaction processtemperature). 


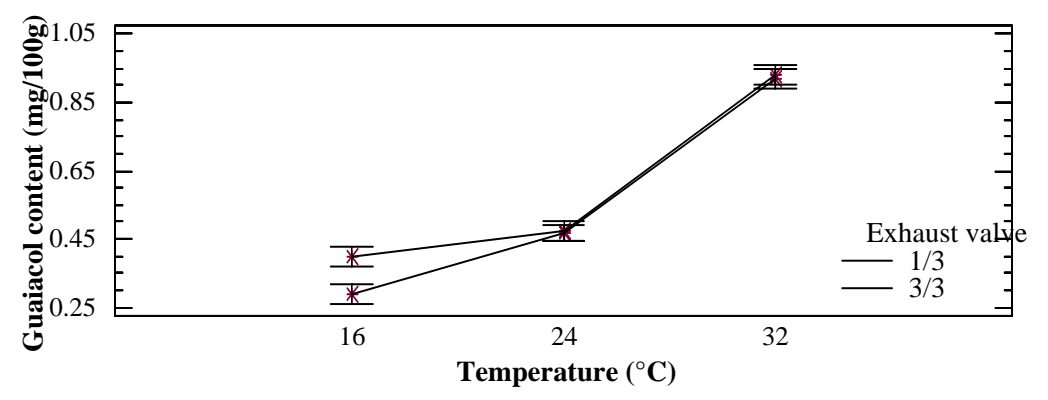

A

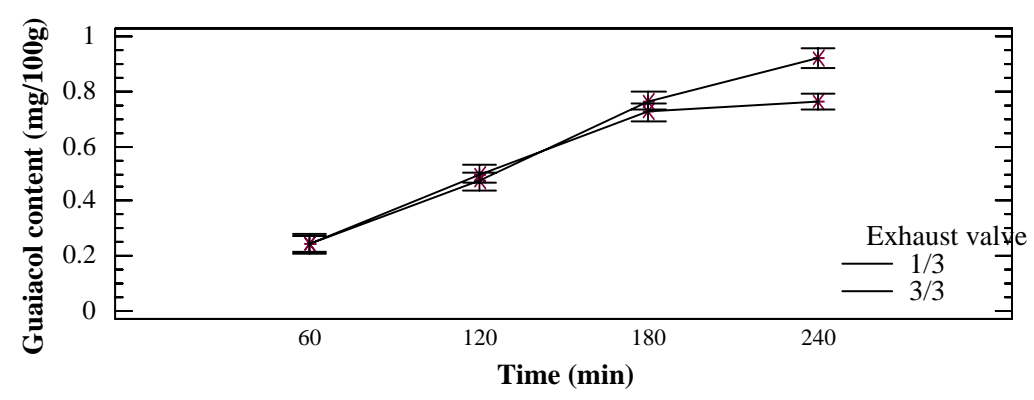

B

Fig.7. Effect of smoke resident time in smokehouse on phenolic compounds content of herring fillets. A: effect of valve position-temperature interaction. B: effect of exhaust valve position-smoking time interaction.(95\% LSD interval are represented). 


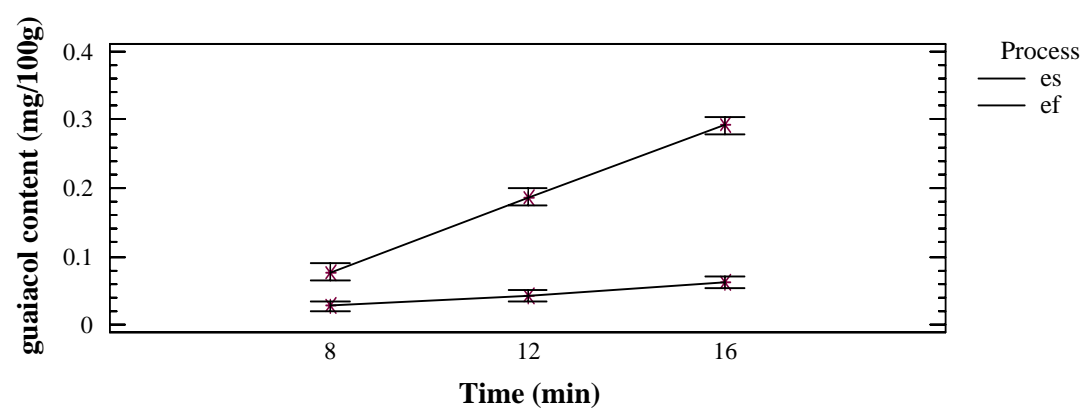

A

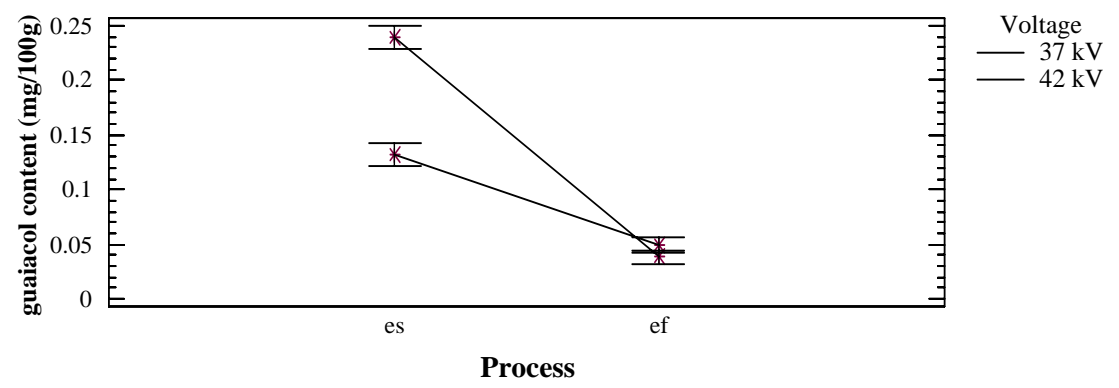

B

Fig. 8 Representation of significant parameters interactions in electrostatic processes (A: effect of interaction between process and time on guaiacol content, B: effect of interaction between process and voltage on guaiacol content) 


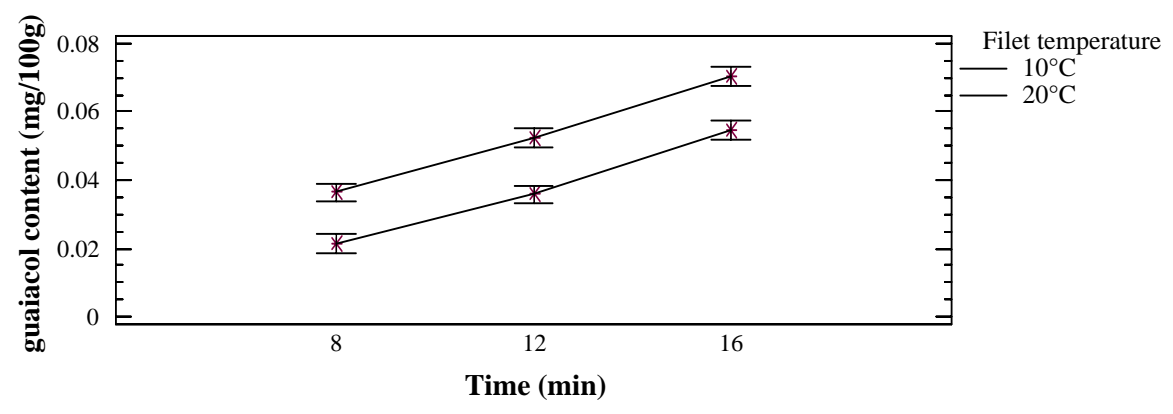

A

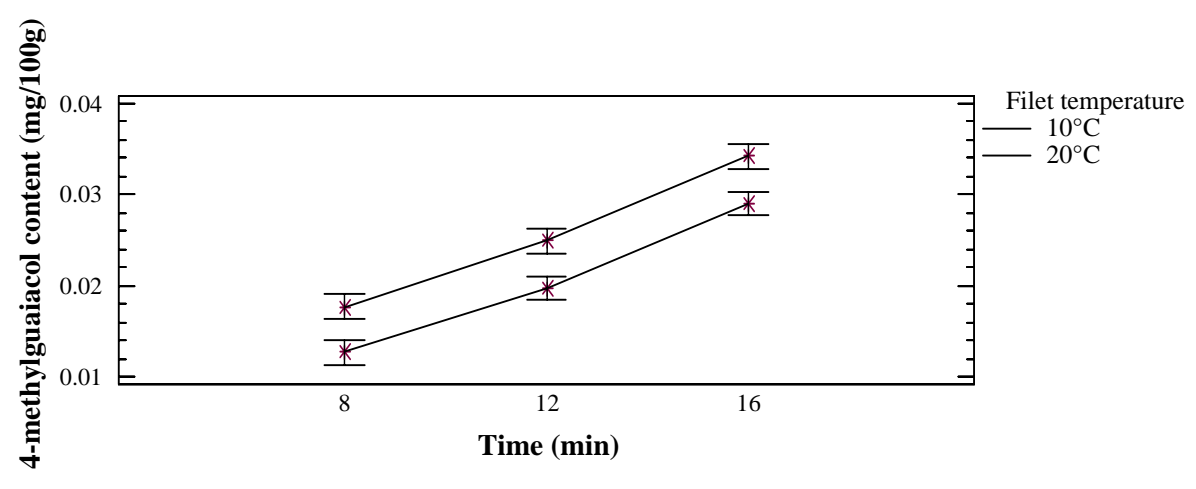

B

Fig. 9. Effect of interaction between initial fillet temperature and smoking time on content of phenolic compounds obtained by electrostatic process using friction smoke production (95\% LSD intervals are represented). 
Table 1 Process and experimental conditions used to measured kinetic deposition of phenolic compounds into fish muscle.

\begin{tabular}{llll}
\hline & $\begin{array}{l}\text { Traditional smoking } \\
\text { (Smouldering (sp) } \\
\text { and friction(fp)) }\end{array}$ & $\begin{array}{l}\text { Liquid smoke } \\
\text { atomisation(ls) }\end{array}$ & $\begin{array}{l}\text { Electrostatic smoking } \\
\text { (Smouldering (es) and } \\
\text { friction( ef)) }\end{array}$ \\
\hline Initial product temperature $\left({ }^{\circ} \mathrm{C}\right)$ & 10 & 10 & $10-20$ \\
Smokehouse temperature $\left({ }^{\circ} \mathrm{C}\right)$ & $16-24-32$ & $16-24-32$ & \\
Smoking duration (min) & $60-120-180-240$ & $60-120-180-240$ & $4-8-12-16$ \\
Exhaust valve opening & $1 / 33 / 3$ & closed & Positive \\
Tension polarity & & & $37-42-$ \\
Tension value $(\mathrm{KV})$ & & & \\
\hline
\end{tabular}


Table 2 Average and standard deviation of phenolic compounds percentages for each studied process

\begin{tabular}{|c|c|c|c|c|c|c|c|c|c|c|}
\hline & \multicolumn{2}{|c|}{ smouldering } & \multicolumn{2}{|c|}{ liquid smoke } & \multicolumn{2}{|c|}{ friction } & \multicolumn{2}{|c|}{ electrostatic friction } & \multicolumn{2}{|c|}{$\begin{array}{l}\text { electrostatic } \\
\text { smouldering }\end{array}$} \\
\hline & $\begin{array}{l}\text { Percentage } \\
\text { mean }\end{array}$ & $\begin{array}{l}\text { Standard } \\
\text { deviation }\end{array}$ & $\begin{array}{l}\text { Percentage } \\
\text { mean }\end{array}$ & $\begin{array}{l}\text { Standard } \\
\text { deviation }\end{array}$ & $\begin{array}{c}\text { Percentage } \\
\text { mean }\end{array}$ & $\begin{array}{l}\text { Standard } \\
\text { deviation }\end{array}$ & $\begin{array}{c}\text { Percentage } \\
\text { mean }\end{array}$ & $\begin{array}{l}\text { Standard } \\
\text { deviation }\end{array}$ & $\begin{array}{c}\text { Percentage } \\
\text { mean }\end{array}$ & $\begin{array}{r}\text { Standard } \\
\text { deviation }\end{array}$ \\
\hline phenol & 10.2 & 1.2 & 8.7 & 1.2 & 8.7 & 0.7 & 4.9 & 1.7 & 13.6 & 1.5 \\
\hline o-cresol & 4.2 & 0.45 & 2.7 & 0.4 & 3.0 & 0.5 & 2.8 & 2.3 & 4.4 & 0.7 \\
\hline p-cresol & 2.2 & 0.3 & 2.2 & 0.6 & 2.8 & 0.3 & 2.1 & 1.3 & 3.0 & 0.5 \\
\hline guaiacol & 33.7 & 2.9 & 39.2 & 4.9 & 26.2 & 1.4 & 26.3 & 7.1 & 33.1 & 3.9 \\
\hline 4-methylguaiacol & 24.0 & 2.0 & 24.4 & 1.6 & 21.2 & 1.9 & 16.2 & 5.2 & 23.0 & 3.1 \\
\hline 4-ethylguaiacol & 4.8 & 0.6 & 4.3 & 0.7 & 4.2 & 0.5 & 2.9 & 1.2 & 5.1 & 0.6 \\
\hline syringol & 13.0 & 3.9 & 8.6 & 3.1 & 19.6 & 2.2 & 27.6 & 3.2 & 22.2 & 2.8 \\
\hline eugenol & 3.5 & 1.1 & 8.2 & 1.7 & 4.0 & 1.0 & 9.3 & 2.5 & 2.2 & 1.8 \\
\hline 4-propylguaiacol & 0.8 & 0.1 & 1.0 & 0.3 & 0.8 & 0.2 & 0.6 & 0.4 & 0.6 & 0.4 \\
\hline isoeugenol & 3.5 & 1.9 & 1.8 & 0.7 & 8.8 & 4.3 & 6.9 & 2.1 & 0.6 & 0.4 \\
\hline
\end{tabular}

